\title{
NARRATIVE-BASED INTERVENTION AND EMOTIONAL INTELLIGENCE IN FEMALE CHILDREN
}

Yasaman Ghafaryan Shirazi

https://orcid.org/0000-0002-0108-4221

Scopus Author ID: $\underline{57209177259}$

yasaman.ghafaryanshirazi@tuni.fi

University of Tampere, Finland

University of Medical Sciences, Iran

Raija-Leena Punamäki https://orcid.org/0000-0003-4385-3073

Scopus Author ID: 7004038427 raija-leena.punamaki-gitai@tuni.fi

University of Tampere, Finland

Kirsi Peltonen http://orcid.org/0000-0002-5112-3823

Scopus Author ID: $\underline{36057342100}$

kirsi.peltonen@utu.fi

University of Turku, Finland

Mohammad Malekzadeh

https://orcid.org/0000-0002-0451-0097

Scopus Author ID: $\underline{54990420300}$

mzh541@yahoo.com

University of Medical Sciences, Iran

Ozra Esmaeili

hadi00767@yahoo.com

Yasuj Technical and Vocational University, Iran

Received April 3, 2021; Revised June 8, 2021; Accepted June 24, 2021

\begin{abstract}
Children share their emotional experiences through narratives, and high-quality narratives are beneficial for their wellbeing and development. This research investigated whether narrative-based interventions in the school context can increase children's emotional intelligence (EI). It tested three intervention settings' effect in their oral and written narrative elements: 1) oral co-narration, 2) literary narrative, and 3) merging co-narrating and literary narrative. The sample consisted of 91 female Iranian students (age $=12 \pm .21$ ), who were selected randomly to these three intervention groups where they received a two-month training and one control conditions with

(C) Shirazi, Yasaman Ghafaryan; Punamäki, Raija-Leena; Peltonen, Kirsi; Malekzadeh, Mohammad; Esmaeili, Ozra, 2021. This is an Open Access article distributed under the terms and conditions of the Creative Commons Attribution 4.0 International Licence (http://creativecommons.org/licenses/by/4.0).

East European Journal of Psycholinguistics, 8(1), 95-109. https://doi.org/10.29038/eejpl.2021.8.1.shi
\end{abstract}


treatment as usual. The Emotional Quotient inventory, the youth version (EQ-i: yv) test, was used to measure the students' EI levels before and after the intervention. The results demonstrated that oral and written narrative have different effects on student's EI. The results revealed a significant increase in the EI score among children who participated in the oral co-narrating group and merged co-narrating and literary narrative intervention group. In contrast, the literary narrative intervention was not effective enough to increase children's EI. In conclusion, oral and written language modes and their merged narrative elements are crucial when tailoring effective schoolbased interventions to impact students' EI with language minority. Educators need to apply the oral and written narrative elements in their instructional design of the EI interventions considering the narrative style of students. In particular, oral language as the developmentally and socioculturally appropriate tool can involve student's more with making sense of text and thereby support the learning process in EI interventions.

Keywords: emotional intelligence, oral language and literacy, perspective-taking, empathy, school-based intervention, Iranian female children.

\section{Шіразі Ясаман Гафарян, Пунамекі Райя Лсена, Пелтонен Кірсі, Малекзадег Могаммад, Есмаелі Озра. Наративно-базовані інтервенції та емоційний інтелект у дівчаток.}

Анотація. Діти передають свої емоційні переживання за допомогою наративів, при цьому якісно оповідані наративи здійснюють позитивний вплив на їхнє благополуччя та розвиток. Метою цього дослідження $є$ вивчення того, чи можуть втручання на основі наративів у шкільному контексті підвищити емоційний інтелект (EI) дітей. У дослідженні здійснювалася перевірка ефективності трьох видів втручань, базованих на усних та письмових наративах: 1) усний спів-наратив, 2) письмовий наратив та 3) сполучення усного спів-наративу та письмового наративу. Вибірка містила 91 іранських дітей жіночої статі (вік=12士.21), яких випадковим чином відібрали до цих трьох груп, де упродовж двох місяців вони застосовували наративи. Для чистоти експерименту також була сформована контрольна група, у яких навчання відбувалося у звичний спосіб. Для вимірювання рівня ЕI учениць до та після втручання застосовано методику The Emotional Quotient, версію для юнаків (EQ-i: yv). Результати дослідження показали, що усний та письмовий наративи порізному впливають на ЕI учениць. Зафіксовано значне збільшення рівня ЕI серед дітей, які брали участь у групі співнараторів, а також у групі, де спів-наратив використовувався разом із письмовим наративом. Водночас, інтервенція лише на основі письмового наративу виявилася недостатньо ефективною для підвищення рівня ЕI у дітей. Результати дослідження свідчать про те, що спільне використання усної та писемної форм наративів мають вирішальне значення при розробці ефективних інтервенцій у школі для впливу на ЕI учнів - представниць мовних меншин. Педагоги повинні застосовувати у комплексі усні та писемні наративи учнів для підвищення їхнього ЕI. Зокрема усне мовлення як інструмент для вікового та соціо-культурного розвитку дітей може більшою мірою залучати учнів до осмислення тексту і тим самим підтримувати процес навчання на основі інтервенцій, спрямованих на підвищення ЕI.

Ключові слюва: емоційний інтелект, усне мовлення та грамотність, перспектива, емпатія, інтервенція у шкільних умовах, іранські дівчатка.

\section{Introduction}

Emotional intelligence (EI) has been praised as one of the underlying elements of twenty-first-century skills in schools. EI refers to the abilities to perceive, understanding and regulating one's own and others' emotions, which greatly facilitates effective thinking and adaptive behaviour (Mayer, Salovey, Caruso, \& 
Cherkasskiy, 2011). Ample evidence shows high EI have multiple beneficial impacts on children's wellbeing and development, including good academic performance (Hogan et al., 2010), mental and somatic health (Martins, Ramalho, \& Morin, 2010), and social relationships (Lopes et al., 2004). Therefore, several school-based interventions have been developed to enhance children's EI through non-narrative elements such as games, art projects, drawing faces expressing different feelings, class discussion. These interventions have also applied narrative practices such as reading literary narrative and using co-narrative moves of naming and explaining emotions to scaffold students' conflict narrative. For examples, the promoting alternative thinking (PATH) and the RULER EI and Voices, Love, and Freedom (VLF) and the Reading, Writing, Respect, and Resolution (4Rs) have applied a combination of these narrative practices (Greenberg \& Kusché, 2006; Nathanson, Rivers, Flynn \& Brackett, 2016; McTigue, Douglass, Wright, Hodges \& Franks, 2015; Lobron \& Selman, 2007; Jones et al., 2010) to promote student's social and emotional understanding.

Emotions tend to be socially shared (Rimé, 2009). The narrative is a human being natural way of sharing one's experiences. Narratives refer to symbolic representation having a temporal format that simulates a sequential construction of reality that causally link together various aspects of experiences such as events, actions, people, subjective interpretations of events and emotions (Bruner, 1991). Although narrative practices are a common part of the EI-enhancing interventions, less is understood about what particular narrative elements may promote EI. This study examines the effectiveness of three kinds of narrative-based intervention settings that differ in oral or written modes.

\section{Elements of narrative-based interventions}

\section{Co-narrating}

Children learn their narrative skills initially in linguistically scaffolded interactions with their mothers and later other family members and peers (Fivush, Reese, \& Haden, 2006; Fivush, 2007). Fivush and her colleagues' following the Vygotskian tradition (Vygotsky,1978) demonstrated that mothers who used elaboration as a specific narrative style have children who narrate, remember and understand emotions better than other children. Mothers with elaborative narrative style typically add new information, elements, emotions, and experiences to their narratives by using multiple questions and statements such as "what did we do at the park" and providing evaluative feedback to the children by confirming and praising, providing subjective perspective on a shared event (Fivush et al., 2006). In optimal co-narratives, parents calibrate their style and message according to children's age and developmental achievements.

Graneist and Habermas (2019) study indicated that mothers use age-sensitive strategies to scaffold adolescents' narrative to support their emotional understanding. For example, in the co-narration of peer conflict in school, mothers encourage her 
child to narrate the events step by step. Then, support the child to verbally report and label emotions in a more differentiated way and explain the child's sadness or anger by providing the alternative motive for other's actions. Mothers' co-narrative moves of naming and explaining emotions are especially salient for adolescents' development since the representation of character as a mental agent with emotions and thoughts in children's narrative is still developing. By adolescence, children become able to represent a character's internal mental state in a more complex way and explain the character's actions with reference to their emotions and thoughts (Nicolopoulou \& Richner, 2007; De Silveira \& Habermas, 2011). In contrast, mothers who used repetitive reminiscing style asked few redundant questions and thus failed to enrich their children's narratives. As such, they probe the past event without providing new details, shared observations or novel ways of telling the narrative plots (Fivush et al., 2006; Fivush, 2007).

The current study adopts the concept of maternal elaborative narrative style ability to explore the effect of narrative co-construction of emotional experiences in the school context. Teachers and children construct classroom discourse forms; however, the teacher defines the privileged culture and discourse in the classroom. Thus, this study views the teachers' co-narrative scaffolding of emotional experience as an initial learning space for children to name and make sense of their emotions, followed by student's autonomous collaborative co-narration in peer groups.

\section{Oral and written narrative language modes}

Narratives are presented and shared orally through spoking and literally through written text. Oral and written narrative strategies are different in two ways (Gee, 2015). First, the speaker reveals their attitude toward the story's message and evaluates by dramatizing or implying the point through paralinguistic and nonverbal channels. For example, the story is said in some tone of voice, with some expression in the voice and face of the narrator . In contrast, the writer's evaluation or attitude toward the messages must be lexicalized. For example, writers can evaluate the story by careful choice of words, explicit statement, and complex syntax. Second, the oral narrative is highly contextualized because the speaker and co-narrators are co-present in time and space. For example, the speaker can say: "look at this". In contrast, in the typically written narrative genre, the immediate context is lost in the sense that the writer and reader and writer are typically separated in time and place (Gee, 2015).

Different cultures had different preferences for oral or written, literate based, mode of communication (Gee, 2015). Euro-American typically value the features of written language in their narrative style. As such they typically less emphasis on interpersonal involvement and more focus on information conveyed while African and Middle Eastern cultures cherish features of orality and more relative focus on interpersonal involvement especially performance, communication and speaker's reactions (Marzolph, 2020; Gardner-Neblett, Pungello \& Iruka, 2012). Many studies on the differences between oral and literate strategies in discourse have explained 
the failure of certain ethnic groups in schools (Lee,2007; Gee, 2015). The Iranian school children participating in this study are from Lur ethnic-cultural group with a unique culture, including distinctive lifestyle and traditional folklore songs. Historically, pastoral nomadic tribes formed the majority of the Lur population. Nowadays, they are divided into groups living in sedentary life and nomads (Bakhtiari). The Lur ethnic group speaks their distinct dialect close to Persian (Farsi), although children use the official written language, Farsi, in their school.

The present study examines whether narrative-based intervention can increase student's EI and whether oral and written narrative elements have a different effect on students' EI. The compared narrative-based interventions using written narrative differed in their instructional approach toward literacy. The literary narrative group designed based on explicit instruction on the psycholinguistic processes of literacy that views literacy as a socially isolated process by the reader and the writer. In contrast, the merged group was designed based on the social interactionist theories of literacy (Lawrence \& Snow, 2010), which view literacy as a social process. As such, the construction of written narratives in a school context is influenced by the official discourse model of the school culture, i.e., school standard discourse, and the parallel unofficial discourse pattern of the other cultural contexts such as peer and home culture (Lee, 2007).

\section{Literary narrative}

This study's perspective on the effect of reading and writing literary narratives on student's EI is inspired by Oatley and his colleagues' communicative theory of emotion. According to their theory, in real life, individuals use the cognitive mechanism by which Oatley called a planning processor to develop plans to achieve goals. In reading fiction, individuals simulate the same planning processor to adopt one or more goals of the protagonist or other characters to identify and recognize external patterns of events and how they concern the story characters. In this sense, the failure and success of the protagonist's goals and plans elicit negative and positive emotions (Oatley \& Johnson-Laird, 2014). Drawing inferences about the character's intention requires perspective-taking to enhance the reader's social understanding and empathy (Lobron \& Selman, 2007). The study by Mar, Oatley \& Peterson (2009) delineated that fiction readers have greater empathy than nonfiction readers. The current study examined the effectiveness of an intervention involving written composed narratives or reading and writing fictional stories on student's EI.

\section{Method}

\section{Participants}

The data was collected in schools of Yasuj city in Southwest of Iran. The participants have Lur ethnicity and speak the Lurish language (closely related to 
Persian). The sample consisted of 91, 12 years old female students $(M=12, S D=$ \pm .21 ). The Participants were selected using cluster sampling; all the city schools grouped into clusters according to their location area in the city from the list of public schools provided by the Ministry of Education. We randomly selected four areas in the city, four secondary schools, and four sixth-grade classrooms. The size of the groups was oral narrative $(n=22)$, written narrative $(n=20)$, mixed group $(n=16)$, and the control group $(n=33)$.

\section{Procedure}

This study received approval from the Ethical Committee of Yasuj University of Medical Sciences. After obtaining the necessary permissions from the Ministry of Education and Schoolteachers, the study's objectives were explained to students and their parents and their informed consent was obtained. The interventions were integrated as part of the literature and art curriculum of school classes. All intervention groups received eight weekly 60-minute training sessions. The control participants received no intervention. The study handbook guide was also provided and reviewed with them one session before the interventions started. Teachers accompanied by the researcher in each session and received 15-minute tutoring before them.

\section{Interventions}

\section{Co-narrating}

The training started with the teacher and the researcher performing and conarrating the narrative of a conflicting emotional event. They perform the same narrative in two ways. First, they co-narrated the event while blaming the researcher without including his own and the researcher's perspective, i.e., emotions and needs. Second, they co-narrate the same conflicting event; however, this time, they add their own and the other perspectives using the following guided questions (see table 1).

The aim was to support students to perceive and define the conflict as a shared or mutual concern, taking into account both person's needs and wants. Students received pictures of facial expression of emotions accompanied by emotional words. Students encouraged to practice co-narrating in two steps: (a) recall an emotional event involving a conflict, recount the event. (b) co-narrate the identical event sequences from different perspectives. They practice co-narrating using three sources: following the teacher's narrative as a reference point, asking each other the guided questions, and using the co-narrative moves of naming and explaining emotions. Students tasks were to first, took turns and recalled memories of conflictual emotional incidents, then co-narrate with their friends in groups of four. They tried to draw the narrative of the conflict event on paper. Second, two of the students from each group volunteer to perform the co-narration of conflict narrative 
for the teacher. Finally, they picked one of the recalled stories to perform as a drama in their group.

Table 1

Oral narrative structure and examples

Narrative Units

1. Observation

\section{Recounting Guided Questions}

"What did I and/or others did not include me in the observe?" game"

2. Feeling

"I felt angry, my body felt hot and tense. I want to feel?" yell at you."

3. Need

"Because I have a need to be included." "How did I and/or others

Narrative Example

.
"What did I and/or others need?" (1)

4. Request
"What did I and/or the other can do to satisfy each other's need?"

\section{Literary narratives}

The literacy-based practices involved two steps. Step one, the teacher read out loud the stories, help students to take the hero's and character's perspective (need and feelings). The teacher highlights the strategies the story heroes applied to cope with their emotions. The stories involved themes about anger, fear, shyness, boredom, self-esteem, autonomy, and self-actualization that followed the quest narrative structure, e.g., hero's journey (Vogler, 2007). The story plot consists of a series of events to a high point that revolves around an emotional conflict that the hero confronts and resolves at the end. In step two, students received a notebook, story guide and pictures of facial expression of emotions accompanied by emotional words. Students are instructed to create stories their own stories modelling the teacher's stories (see table 2). Additionally, they asked to illustrate their narrative by painting the story plot. The teacher informs that the stories are not evaluated and do not affect the subject class final score. Students informed that there is no obligation to follow the teacher's stories' structure, and their task is to highlight the story conflict, the character's perspectives and how the protagonist resolves the conflict. 
Table 2

Literary narrative story guide example

\begin{tabular}{lll}
\hline Procedure & Teacher's Modeled Story & Student's Story guide \\
\hline Problem of Hero & Anger & Anger \\
Course of Journey & Little Angry Turtle & Pick the hero character \\
Protecting power & Magical words & Create a theme and setting \\
The Problem Solving & Going inside its shell & $\begin{array}{l}\text { Create the hero's tools and } \\
\text { assistants } \\
\text { Formula }\end{array}$ \\
Exercise the Formula we hero \\
overcome the problem?
\end{tabular}

\section{Merging co-narrating and literary narratives}

Students received the training similar to the co-narrating group followed by composing fictional narratives; however, the only difference was that they compose the fictional narrative in collaboration with their peers through discussion. We designed the training in line with Lee's (2007) cultural modelling approach to build explicitly on students' socio-cultural and linguistic resources.

\section{Measurement}

Children's emotional intelligence was assessed with the Bar-On Emotional Quotient inventory youth version questionnaire (EQ-i: yv). The EQ-i: yv is a 60item self-report measure of emotionally and socially intelligent behaviour developed for children and adolescents aged seven through eighteen (Bar-On \& Parker, 2000). The test has five scales: Intrapersonal, Interpersonal, Adaptability, and Stress Management, which makes up the Total EI score. The fifth scale is General Mood which is not included in the Total EI score. The Total EI describes the overall emotional-social intelligence. The participants are asked to respond in a way that 
best describes how they feel, think, or act in most situations using a four-point Likert scale that ranges between 1 "very seldom or not true of me" and 4 "very often or completely true of me". The validity and reliability of the EQ-i test have been shown by many studies (Wood, Parker \& Keefer, 2009). The reliability studies showed an overall average internal consistency reliability of 0.76 and the test-retest reliability of 0.85 after four months (Bar-On, 1997). In this study, the student's raw scores are converted to standard scores with a mean of 100 and a standard deviation of 15 .

\section{Statistical Analysis}

Data were collected at pre-test on the sample of 91 students. A one-way ANCOVA used to control for the baseline differences between the groups and pretest scores on the outcome measure. The pre-test score was used as the covariate, the EI scores as the dependent variable and the intervention groups were used as the independent variables. Repeated measure ANOVA was not used to analyze the data because the data was not interpretable for the Mauchly test of sphericity. The attrition rate at pre-test was $5.49 \%$ and ate the post-test was $8.79 \%$.

\section{Results}

\section{Descriptive Statistics}

Table 3 presents the education level of the participants. The groups did not differ by levels of parent's education, $\chi^{2}(1, n=91)=0.43, p=.28$.

Table 3

Demographic data on parent's education of the sample

\begin{tabular}{|c|c|c|c|c|c|c|c|c|}
\hline \multirow[t]{2}{*}{ Group } & \multicolumn{2}{|c|}{$\begin{array}{c}\text { Co- } \\
\text { narrating }\end{array}$} & \multicolumn{2}{|c|}{ Literary } & \multicolumn{2}{|c|}{ Merged } & \multicolumn{2}{|c|}{ Control } \\
\hline & $\mathrm{n}$ & $\%$ & $\mathrm{n}$ & $\%$ & $\mathrm{n}$ & $\%$ & $\mathrm{n}$ & $\%$ \\
\hline \multicolumn{9}{|l|}{ Mother's Education } \\
\hline High school or below & 16 & 72.7 & 17 & 85 & 13 & 81.3 & 28 & 84.8 \\
\hline Above high school & 6 & 27.3 & 3 & 15 & 3 & 18.8 & 5 & 15.2 \\
\hline \multicolumn{9}{|l|}{ Father's Education } \\
\hline High school or below & 5 & 22.7 & 10 & 50 & 12 & 75 & 24 & 72.7 \\
\hline Above high school & 17 & 77.3 & 10 & 50 & 4 & 25 & 9 & 27.3 \\
\hline
\end{tabular}

Table 4 provides descriptive statistics and comparisons between the intervention and control groups at baseline. As you can see, the differences in EI scores between groups in the pre-test is not significant. 
Table 4

Descriptive statistics and comparisons between groups at baseline

\begin{tabular}{lllll}
\hline \multirow{2}{*}{ Groups } & \multicolumn{2}{l}{ Pre-test } & & \\
\cline { 2 - 3 } & $M$ & $S D$ & & \\
& $M(3,73)$ & $p$ \\
\hline 1. Co-narrating & 75.02 & 8.1 & .54 & .65 \\
2. Literary narrative & 72.62 & 7.29 & & \\
3. Merged co-narrating and literary & 74.49 & 8.34 & & \\
narrative & & & & \\
4. Control & 72.67 & 7.58 & & \\
\hline
\end{tabular}

\section{Analysis of Covariance}

ANCOVA test indicated a significant effect of Narrative-intervention on students' EI at the $\mathrm{p}<.05$ level for the four conditions $\mathrm{F}(73.3)=17.57, \mathrm{p}<.001, \eta_{\mathrm{p}}{ }^{2}$ $=.41$. Post hoc comparisons using the Bonferroni test showed the mean score for the co-narrating condition, and the merged condition was significantly different from the control condition at post-test. However, the reading and writing literary narrative condition did not significantly differ from the control conditions. Additionally, there was a significant difference in the mean score of the merged condition and the conarrating condition and the literary narrative condition with the co-narrating conditions (see table 5).

Table 5

ANCOVA Comparisons of intervention Groups

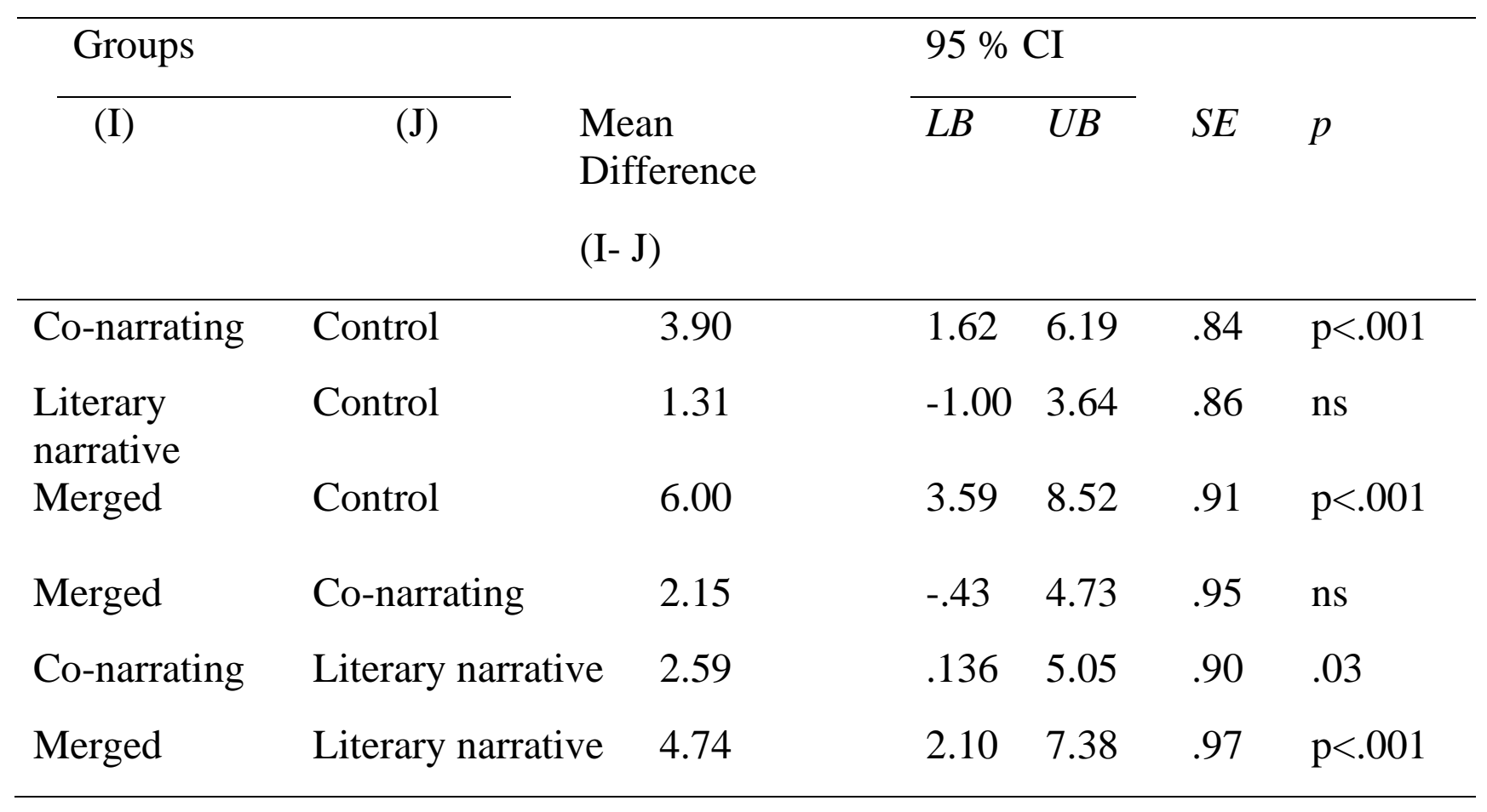




\section{Discussion}

This study explored the effect of narrative practices in three different conditions on student's EI. The study results suggested that narrative intervention do influence EI. Specifically, our results suggest that oral and written narrative had a different effect on EI.

The students who received the oral co-narration indicated an increase in EI score. We assume the teachers' co-narrative scaffolding of emotional experience followed by children's practice of autonomous collaborative co-narration in peer groups supported students to construct more evaluative narrative. For example, following the teacher's elaborative narrative as a reference point, Maryam recalled the emotional episode of conflict with her friend. She co-narrated the event using the guided questions. She added her own and her friend's perspectives (emotions and need) while explaining that "the reason you pushed me is that you were angry and had a need to be included in the game". In this narrative argument, Maryam understands that the cause of her friend's action is anger rooted in the universal human need of being socially included (Rosenberg \& Chopra, 2015). The present findings seem to be consistent with the result from previous studies on the motherchild's narrative co-construction of emotional experiences indicated that mother's use of clear and elaborative discourse in the conversations facilitate children's understanding of emotions (Fivush et al., 2006; Fivush, 2007). Although these findings differ from Fivush, McDermott Sales \& Bohanek (2008) found no relations between mothers' elaborative narrative and children's narrative meaning-making of negative events.

Consistent with the present results, EI interventions such as RULER emphasizes teaching emotion vocabulary and storytelling in its feeling word curriculum. RULER has used step-by-step guided questions, named the Blueprint anchor tool, to scaffold students' narrative of a conflict event using self-reflection and perspective-taking. The blueprint tool guide students to ask questions such as "How did I (and the other person) feel?" and "What caused me (and the other person) to feel this way?" followed by asking oneself questions to reflect on how one can regulate him/her emotions. Likewise (Nathanson, Rivers, Flynn, \& Brackett, 2016). The other EI program, PATH, applied an autobiographical narrative. i.e., telling stories of one's personal experiences as the base of their practices. PATH program integrated emotion vocabularies into the everyday classroom and school routines using storytelling around feelings to promote students' skills in interpersonal problem solving and emotional understanding (Greenberg \& Kusché, 2006).

The result showed that the merged narrative practices increased EI. Based on the social interactionist theories merging oral and written discourse might have provided a meaningful literacy context for students. Children might utilize developmentally appropriate strategies such as play and associative language to 
enhance their writing when they work with peers (Gee, 2015). In line with Lee's (2007) Cultural modelling approach, we assume student might externalize the reading process through classroom dialogue with their peers to draw on their developmentally and socio-culturally appropriate oral language strategies such as playing, explaining, exploring, arguing with language for making sense of literary texts. Studies suggested that discussion with classmates lead students to acquire high-level literacy skills such as interpreting and exploring the perspective of characters and comparing them with their own, which is still developing for adolescent readers (Lawrence \& Snow, 2010; Lee, 2011). A meta-analysis by Murphy, Wilkinson, Soter, Hennessey and Alexander (2009) reported an increase in student-teacher talk and more student engagement in literacy tasks when oral practices such as classroom talks, and literate language tasks are integrated. These results match those observed in the EI program, such as the Reading, Writing, Respect, and Resolution (4Rs) that integrated the oral co-narrative practices: applying interpersonal negotiation strategies and the literacy-based curriculum: story reading and discussion its curriculum (Jones et al., 2010). Many other programs such as PATH and RULER applied both the oral and literary narrative to increase the EI of students (Nathanson, Rivers, Flynn, \& Brackett, 2016; Greenberg \& Kusché, 2006; Jones et al., 2010).

Students in the literary narrative group showed no increase in EI. These students received a teacher's guide on reading and writing literary narrative; however, they practiced literacy as a task that is needed to be done individually. We assume that children might have more difficulty in literacy tasks when the oral language element is missing from the instruction. The point of the story and emotions in the oral practices are conveyed through paralinguistic and non-verbal messages in an immediate shared context with the frequent collaboration of the conarrator. In contrast, writing language conveys meaning only through the verbal channel. It put additional cognitive demands on children to provide contextual information and emotional signals such as tone of voice and facial expressions through lexicalization (Gee, 2015). Additionally, we assume that due to their cultural background, students might have preferred the oral narrative tradition influenced by the speech styles of their community (Marzolph, 2020).

In composing narrative with teachers, children tend to talk, and act based on previous plans and avoid spontaneous talk to take the less intellectual risk. In the merged group, students wrote narrative with peers through classroom talk. Therefore, children might make sense of the stories in peer interaction using the narrative style of their community and interpret text with equally novice peers (Blum-Kulka \& Snow, 2004). In contrast, in the literary narrative group, students wrote narrative with teachers who tend to use expert strategies. Thereby, children only have access to the privileged discourse model of the school culture. Even though teacher's discourse may support the structure or cognitive aspect of writing, 
it may not have provided children with specific social and affective contexts like collaborative narratives to support their sense-making process (Lee, 2007).

\section{Conclusion}

This study extended previous studies investigating the oral and written narrative elements and their specific effects on students' EI. The majority of previous research on using narrative practices in increasing EI comes from the white western sample. Thus, this study contributes to the better implication of narrative in EI programs considering the narrative style of students with different cultural backgrounds. Oral language strategies as the developmentally and socio-culturally appropriate tool can be applied in literacy practices and instruction to involve student's more with making sense of text which may subsequently facilitate the learning process in EI interventions. In contrast, solitary literacy practices in EI education might mismatch between the students' primary discourse and meaning making processes, and the discourse valued at school.

\section{Limitations and Future Directions}

The results should be interpreted cautiously since the result might only reflect the short-time effect of the interventions. The study did not measure the long-term effect of the interventions through follow-up measurements of the outcome. Besides, the students' EI measured by self-report test; thus, the result may be affected by social desirability bias. Future studies could measure EI using performance-based measurements to examine the difference in the results. Also, the study included only one class per condition; thus, the difference in school, staff, teachers, or students in each condition may have acted as mediator and affected the study results. Finally, the study should be generalized with caution to other situations since the sample consisted of only female students, age: 12, with a Middle Eastern background. Futures studies recommended investigating the different effects of emotional expression in oral and written narrative modes. These differences may assist educators to customize the use of oral and written narrative in EI education, considering student's developmental status and socio-cultural differences to optimize its effects.

\section{References}

Bar-On, R., \& Parker, J. D. A. (2000). The BarOn Emotional Quotient Inventory: Youth Version (EQ-i:YV) Technical Manual. Toronto, Canada: Multi-Health Systems, Inc.

Blum-Kulka, S., \& Snow, C. E. (2004). Introduction: The Potential of Peer Talk. Discourse

Studies, 6(3), 291-306. https://doi.org/10.1177/1461445604044290

Bruner, J. (1991). The narrative construction of reality. Critical Inquiry, 18(1), 1-21. 
de Silveira, C., \& Habermas, T. (2011). Narrative means to manage responsibility in life narratives across adolescence. The Journal of Genetic Psychology: Research and Theory on Human Development, 172(1), 1-20. https://doi.org/10.1080/00221325.2010.503254

Fivush, R., Haden, C. A., \& Reese, E. (2006). Elaborating on elaborations: Role of maternal reminiscing style in cognitive and socioemotional development. Child Development, 77(6), 1568-1588. https://doi.org/10.1111/j.1467-8624.2006.00960.x

Fivush, R. (2007). Maternal reminiscing style and children's developing understanding of self and emotion. Clinical Social Work Journal, 35(1), 37-46. https://doi.org/10.1007/s10615-006$\underline{0065-1}$

Fivush, R., McDermott Sales, J., \& Bohanek, J. G. (2008). Meaning making in mothers' and children's narratives of emotional events. Memory, 16(6), 579-594. https://doi.org/10.1080/09658210802150681

Gardner-Neblett, N., Pungello, E. P., \& Iruka, I. U. (2012). Oral narrative skills: Implications for the reading development of African American children. Child Development Perspectives, 6(3), 218-224. https://doi.org/10.1111/j.1750-8606.2011.00225.x

Graneist, A., \& Habermas, T. (2019). Beyond the text given: Studying the scaffolding of narrative emotion regulation as a contribution to Bruner and Feldman's cultural cognitive developmental psychology. Integrative Psychological and Behavioral Science, 53(4), 644660. https://doi.org/10.1007/s12124-019-9474-x

Gee, J. (2015). Social Linguistics and Literacies: Ideology in Discourses (5th ed.). Routledge. https://doi.org/10.4324/9781315722511

Greenberg, M. T., \& Kusché, C. A. (2006). Building social and emotional competence: The PATHS curriculum. In S. R. Jimerson \& M. Furlong (Eds.), Handbook of school violence and school safety: From Research to Practice (p. 395-412). Lawrence Erlbaum Associates Publishers.

Hogan, M. J., Parker, J. D. A., Wiener, J., Watters, C., Wood, L. M., \& Oke, A. (2010). Academic success in adolescence: Relationships among verbal IQ, social support and emotional intelligence. Australian Journal of Psychology, 62, 30-41. https://doi.org/10.1080/00049530903312881

Jones, S. M., Brown, J. L., Hoglund, W. L., \& Aber, J. L. (2010). A school-randomized clinical trial of an integrated social-emotional learning and literacy intervention: Impacts after 1 school year. Journal of Consulting and Clinical Psychology, 78(6), 829. https://doi.org/10.1037/a0021383

Lawrence, J., \& Snow, C. (2010). Oral discourse and reading. In M. Kamil, P. D. Pearson, E. Moje, \& P. Afflerbach (Eds.), Handbook of Reading Research, 4, (pp. 320-338). New York, NY: Routledge.

Lee, C. D. (2007). Culture, literacy, and learning: Taking bloom in the midst of the whirlwind. New York, NY: Teachers College Press.

Lobron, A., \& Selman, R. (2007). The interdependence of social awareness and literacy instruction. The Reading Teacher, 60(6), 528-537. https://doi.org/10.1002/trtr.1377

Lopes, P. N., Brackett, M. A., Nezlek, J. B., Schutz, A., Sellin, I., and Salovey, P. (2004). Emotional intelligence and social interaction. Personality and Social Psychology Bulletin 30, 1018-34. https://doi.org/10.1177/0146167204264762

Mar, R. A., Oatley, K., \& Peterson, J. B. (2009). Exploring the link between reading fiction and empathy: Ruling out individual differences and examining outcomes. Communications, 34, 407-428. https://doi.org/10.1515/COMM.2009.025

Martins, A., Ramalho, N., \& Morin, E. (2010). A comprehensive meta-analysis of the relationship between emotional intelligence and health. Personality and Individual Differences, 49(6), 554-564. http://dx.doi.org/10.1016/j.paid.2010.05.029

Marzolph, U. (2020). In and Out of the Nights: The Thousand and One Nights as an Introduction to Middle Eastern Narrative Culture. In O. Elmaz, (Ed.), Endless Inspiration: One 
Thousand and One Nights in Comparative Perspective (pp. 215-242). Gorgias Press. https://doi.org/10.31826/9781463241872-009

Murphy, P. K., Wilkinson, I. A. G., Soter, A. O., Hennessey, M. N., \& Alexander, J. F. (2009). Examining the effects of classroom discussion on students' high-level comprehension of text: A meta-analysis. Journal of Educational Psychology, 101, 740-764.

Mayer, J. D., Salovey, P., Caruso, D. R., Cherkasskiy, L. (2011) Emotional Intelligence. In Sternberg, R. J., \& Kaufman, S. B. (Ed.), The Cambridge handbook of intelligence (pp. 528549). Cambridge University Press. https://doi.org/10.1017/CBO9780511977244.027

McTigue, E., Douglass, A., Wright, K. L., Hodges, T. S., \& Franks, A. D. (2015). Beyond the story map: Inferential comprehension via character perspective. The Reading Teacher, 69(1), 91-01. https://doi.org/10.1002/trtr.1377

Nathanson, L., Rivers, S. E., Flynn, L. M., \& Brackett, M. A. (2016). Creating emotionally intelligent schools with RULER. Emotion Review, 8(4), 305-310. https://doi.org/10.1177/1754073916650495

Nicolopoulou, A., \& Richner, E. S. (2007). From actors to agents to persons: The development of character representation in young children's narratives. Child Development, 78(2), 412-429. https://doi.org/10.1111/j.1467-8624.2007.01006.x

Oatley, K., \& Johnson-Laird, P. N. (2014). Cognitive approaches to emotions. Trends in Cognitive Sciences, 18(3), 134-140. https://doi.org/10.1016/j.tics.2013.12.004

Rimé, B. (2009). Emotion elicits the social sharing of emotion: Theory and empirical review. Emotion Review, 1, 60-85. https://doi.org/10.1177/1754073908097189

Rosenberg, M., \& Chopra, D. (2015). Nonviolent Communication: A Language of Life: LifeChanging Tools for Healthy Relationships. Puddle Dancer Press.

Vogler, C. (2007). The Writer's journey. Studio City: Michael Wiese Productions.

Vygotsky, L. S. (1978). Mind in society: The development of higher psychological processes. Cambridge, MA: Harvard University Press.

Wood, L. M., Parker, J. D., \& Keefer, K. V. (2009). Assessing emotional intelligence using the Emotional Quotient Inventory (EQ-i) and related instruments. In Stough, C., Saklofske, D. H., \& Parker, J. D (Eds.), Assessing Emotional Intelligence (pp. 67-84). Springer, Boston, MA. 